\title{
Reproductive biology of the orangefin ponyfish Photopectoralis bindus (Valenciennes, 1835) off Mangaluru coast, Karnataka
}

\author{
SHOBHA RAWAT, JITENDRA KUMAR*, S. BENAKAPPA, MAHESH CHAND SONWAL \\ AND KUMAR A. S. NAIK \\ Department of Fisheries Resource Management, College of Fisheries, Karnataka Veterinary, Animal and Fisheries \\ Sciences University, Mangalore - 575002, Karnataka, India \\ *Department of Fisheries Resource Management, College of Fisheries, Guru Angad Dev Veterinary and Animal \\ Sciences University, Ludhiana - 141 001, Punjab, India \\ e-mail: shobhirawat@gmail.com
}

\begin{abstract}
The spawning periodicity of Photopectoralis bindus (Valenciennes, 1835) was studied off Mangaluru coast from September 2015 to April 2016 using 490 specimens with total length $6.8-12.3 \mathrm{~cm}(9.6 \pm 0.9 \mathrm{~cm})$ and body weight $4.6-30.28 \mathrm{~g}(14.20 \pm 3.59 \mathrm{~g})$. Results indicated that the average sizes at maturity were $9.3 \mathrm{~cm}$ (males) and $9.5 \mathrm{~cm}$ (females). The male-female ratio was 1:0.72. Absolute fecundity estimated was $9349 \pm 853$ eggs that increased with fish size $\left(\mathrm{R}^{2}=0.92\right)$. Higher gonado-somatic index (GSI) was observed in post-monsoon season with peak value in December (female: $3.39 \pm 1.00 \%$; male: $2.84 \pm 0.796 \%$ ) indicating seasonal spawning of the fish.
\end{abstract}

Keywords: Fecundity, Orangefin ponyfish, Photopectoralis bindus, Spawning periodicity

Silverbellies (Perciformes: Leiognathidae) are benthopelagic fishes dispersed in Indo-Pacific Ocean, contributing to a significant share in the marine fish landings in India (Kizhakudan and Reddy, 2012). They formed $2.34 \%$ of the all India total marine landings in 2017 (CMFRI, 2018). Silverbellies are important constituents of demersal finfish landings along the Indian coastline, particularly by trawl nets (Murty et al., 2003). They are bottom dwelling fishes in shallow coastal waters and their seaward distribution is only up to a depth of $30 \mathrm{~m}$ with several species entering brackishwaters, especially river estuaries. They are locally known as Kuruchi in Kannada, Mullen in Malayalam, Kallikaral in Tamil and Karlu in Telugu.

Silverbellies are small sized, with lengths ranging from 10.0 to $17.0 \mathrm{~cm}$. Of the 49 valid species reported world over, about 26 species are reported from Western Indian Ocean (Fricke and Eschmeyer, 2009). The highly diverse group, represented mainly by 21 species belonging to three traditional genera viz., Leiognathus, Gazza and Secutor, is reported from the east and west coasts of India (Murty et al., 2003), particularly along the coasts of Veraval, Mangaluru, Calicut, Cochin, Palk bay, Gulf of Mannar, Chennai, Kakinada, Visakhapatnam and West Bengal (Abraham et al., 2010). Presently the classification has been updated to include new and valid nomenclature comprising 9 genera i.e., Deveximentum, Equulites, Eubleekeria, Photopectoralis, Gazza, Leiognathus, Aurigequula, Karalla and Nuchequula based on morphological characteristics (Wiadnya et al., 2014).

The present study focuses on the orangefin ponyfish, Photopectoralis bindus (Valenciennes, 1835). It is deeply oval in shape and has a strongly compressed and ventrally convex body. The mouth is protracted, pointing forward to slightly downward. The spinous part of dorsal fin is black at its half height, while the membrane between the second and fifth spines bears a bright orange blotch, turning yellow on preservation in formalin (Abraham et al., 2011). In India, the maturation and spawning status of P. bindus has been studied along the coasts of Calicut (Balan, 1963), Kakinada (Murty, 1983) and Vishakhapatnam (Rao, 2015). Information available on the reproductive biology of this species off Mangaluru coast is meagre. Hence, the present study was undertaken to understand the spawning periodicity in $P$. bindus off Mangaluru coast, Karnataka.

The study was carried out from September 2015 to April 2016. Fresh samples were collected twice a week from the landings of artisanal (gillnet) as well as mechanised gears (trawls) at Mangaluru Fishing Harbour $\left(12.8500^{\circ} \mathrm{N} ; 74.8354^{\circ} \mathrm{E}\right)$ operating up to the depth of $30 \mathrm{~m}$. A total of 490 specimens ranging between $6.8 \mathrm{~cm}$ and $12.5 \mathrm{~cm}$ total length (TL) were used for the study. 
The fish were measured for total length and weight to the nearest $0.05 \mathrm{~cm}$ and $0.6 \mathrm{~g}$ respectively and gonads were examined for confirming the sex of each specimen.

Monthly sex ratio was determined and chi-square $(\chi 2)$ test on sex-ratio was done to find out if sex ratio departed significantly from the expected ratio of $1: 1$. Maturity stages were determined following Abraham et al. (2011) based on the macroscopic appearance of the ovary and testes, area occupied in the body cavity as well as based on the microscopic structure of ova. Five maturity stages were recognised viz., stage I - immature, stages II and III - early maturing, stage IV - late maturing and stage $\mathrm{V}$ - mature. Reprersentative samples from the anterior, middle and posterior portions of the ovary (preserved in 5\% neutral formalin) was taken and pooled for equal representation of all stages of ova for estimating ova-diameter frequency. Ova-diameter was measured following Clark (1925), using an ocular micrometer. Frequency distribution in mature ovaries (stages IV onwards) was followed for understanding the periodicity of spawning as per Hickling and Rutenberg (1936) and De Jong (1940). The length at first maturity $\left(\mathrm{L}_{\mathrm{m}}\right)$ was estimated graphically as the length at which $50 \%$ of he fishes were mature. The gonadosomatic index was estimated using the formula: GSI = (Gonad weight/ Total body weight $) \times 100$ (De Vlaming et al., 1982). Fecundity was estimated from 110 mature ovaries. The average fecundity of fishes of each length group against the corresponding average length, body weight and ovary weight was estimated using the equation: $\log \mathrm{Y}=\mathrm{a}+\mathrm{b}$ $\log \mathrm{X})$ (Le Cren, 1951), where $\mathrm{Y}=$ fecundity, $\mathrm{X}=$ length $(\mathrm{cm})$ or weight of fish $(\mathrm{g})$ or ovary weight; $\mathrm{a}=$ intercept; $\mathrm{b}=$ slope).

The overall sex ratio was estimated as 1:0.72 (M:F). Monthly sex ratio indicated dominance of males over females in all the months except in March and January (Table 1). Chi-square analysis indicated that there was a significant difference $(p<0.001)$ between the two sexes in their occurrence in September and April. Rossoni et al. (2010) reported that differential growth of males and females may influence sex ratio, resulting in the predominance of one sex or the other throughout the development stages. Rao et al. (2015) reported significant difference $(\mathrm{p}<0.05)$ between the sexes in $P$. bindus along the east coast of India. Several authors have reported that differential growth, influence of gear selectivity, exploitation rate, coupled with ecological factors such as temperature could cause deviation from the expected sex ratio of 1:1 (male-female) (Bohlen et al., 2008; Imam et al., 2012).

Ova-diameter range was observed to be $0.03-0.13 \mathrm{~mm}$ in stage I and stage II ovaries, $0.13-0.36 \mathrm{~mm}$ in stage III, $0.24-0.45 \mathrm{~mm}$ in stage IV and $0.35-0.49 \mathrm{~mm}$ in stage $\mathrm{V}$, with modes at $0.10,0.11,0.29,0.39$ and $0.46 \mathrm{~mm}$ respectively in each stage (Fig. 1).

The ova in stages I-II ovaries represented immature stock. Two types of ova are present in the ovaries of stages III-V: (i) maturing ova, which are spherical, partially opaque, and heavily yolked with invisible nucleus and (ii) mature ova, which are spherical and opaque with complete yolk deposition. In stage $\mathrm{V}$, ova show a distinct perivitelline space. Three modes in the diameterfrequency distribution were observed in stage III: at 26 md $(1 \mathrm{md}=0.001 \mathrm{~cm})($ mode a), $29 \mathrm{md}$ (mode b) and at 31 md (mode c). Progressing modes from 29, 35 and 39 md were observed in stage IV and $36 \mathrm{md}, 46 \mathrm{md}$ and $49 \mathrm{md}$ in stage $\mathrm{V}$ ovaries. The ova forming a mode at $36 \mathrm{md}$ in stage $\mathrm{V}$ may be at half of the maturation process and may take only less than half the time to ripen and spawn. The ova forming a mode at 46 and 49 md in stage $\mathrm{V}$ are the mature ova and may be released in one batch after a short time. The coexistence of oocytes of almost all maturity stages in the ovaries, in approximately all gravid females sampled pointed to a high spawning frequency. Balan (1963) reported that spawning occurred in P. bindus from December to February at Calicut. Murty (1983) reported

Table 1. Month-wise sex ratio of $P$. bindus

\begin{tabular}{|c|c|c|c|c|c|c|c|c|}
\hline \multirow{2}{*}{ Months } & \multirow{2}{*}{ Total no. of fishes } & \multicolumn{2}{|c|}{ Male (M) } & \multicolumn{2}{|c|}{ Female $(\mathrm{F})$} & \multirow{2}{*}{ M: F } & \multirow{2}{*}{$\chi^{2}$ values } & \multirow{2}{*}{$\mathrm{p}(<0.001)$} \\
\hline & & $\mathrm{N}$ & $\%$ & $\mathrm{~N}$ & $\%$ & & & \\
\hline September 2015 & 37 & 29 & 78.38 & 8 & 21.62 & 1: 0.28 & 11.919 & 0.001 \\
\hline October & 106 & 62 & 58.49 & 44 & 41.51 & 1: 0.71 & 3.057 & 0.080 \\
\hline November & 81 & 43 & 53.09 & 38 & 46.91 & 1: 0.88 & 0.309 & 0.579 \\
\hline December & 134 & 71 & 52.99 & 63 & 47.01 & 1: 0.89 & 0.478 & 0.490 \\
\hline January 2016 & 32 & 15 & 46.88 & 17 & 53.13 & 1: 1.13 & 0.125 & 0.724 \\
\hline February & 51 & 33 & 64.71 & 18 & 35.29 & $1: 0.55$ & 1.471 & 0.225 \\
\hline March & 40 & 16 & 40.00 & 24 & 60.00 & $1: 1.50$ & 0.400 & 0.527 \\
\hline April & 73 & 53 & 72.60 & 20 & 27.40 & 1: 0.38 & 14.918 & 0.000 \\
\hline Pooled & 490 & 288 & 57.96 & 202 & 42.04 & $1: 0.70$ & 15.094 & 0.000 \\
\hline
\end{tabular}




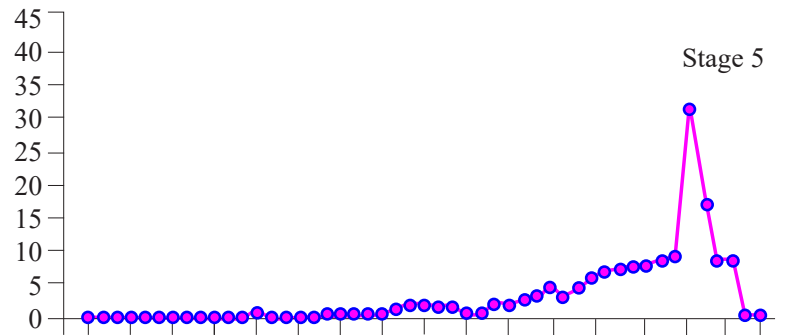

(a)

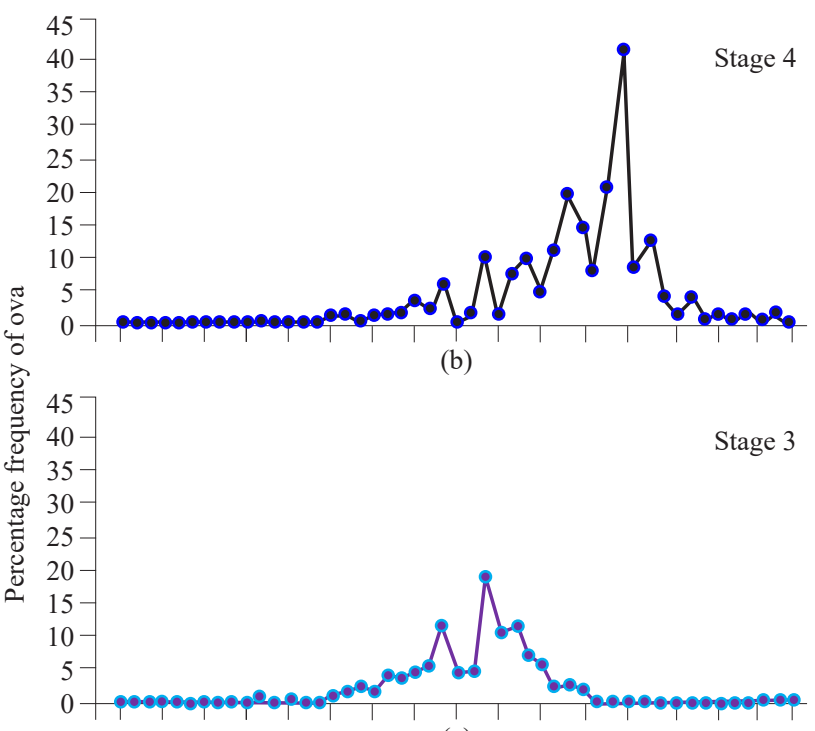

(c)

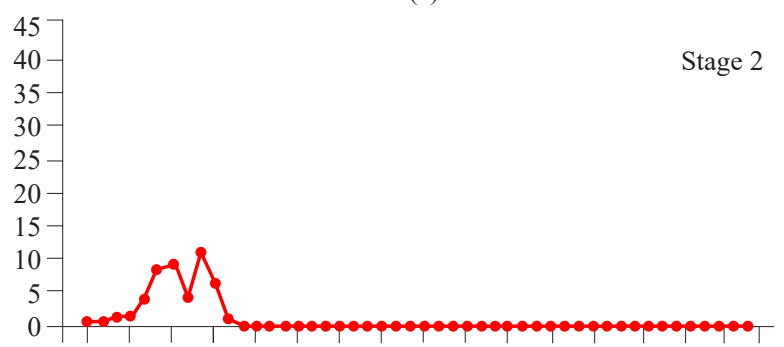

(d)

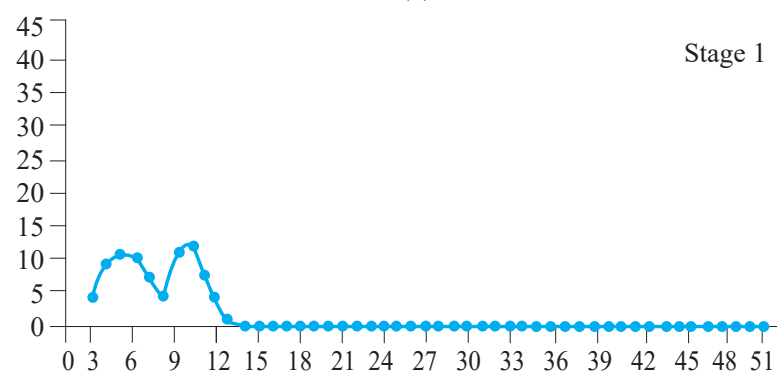

(e)

Fig. 1. Ova-diameter frequency distribution in ovaries $(1 \mathrm{md}=0.001 \mathrm{~cm})$

year-round spawning, with a peak during DecemberFebruary. From the present study, it appears that $P$. bindus is a fractional spawner releasing the mature ova in at least two batches in the course of one year during the spawning season. It shares the same general reproductive features of other silverbellies distributed off the Indian subcontinent, a dieocous species spawning in the marine environment, releasing at least two batches of oocytes throughout an extended spawning season (Murty, 1983).

The occurrence of mature fish showed a gradual increase from $8 \mathrm{~cm}$ until a length of $12.1 \mathrm{~cm}$. Above $12.1 \mathrm{~cm}$, all were mature. The length at maturity was calculated at $9.3 \mathrm{~cm}$ for males and $9.5 \mathrm{~cm}$ for females (Fig. 2). Murty (1983) reported the length at first maturity as $80 \mathrm{~mm}$ for L. bindus from Kakinada. Balan (1963) reported the minimum size (total-length) at first sexual maturity from this species as $87 \mathrm{~mm}$ from Calicut. Rao et al. (2015) reported the mean length at first maturity as $85 \mathrm{~mm}$ in females from Visakhapatnam along the east coast of India. In the present study, it was observed that mature and ovulating females fall in 8.0-12.0 cm length groups, forming the spawning individuals at Mangaluru.

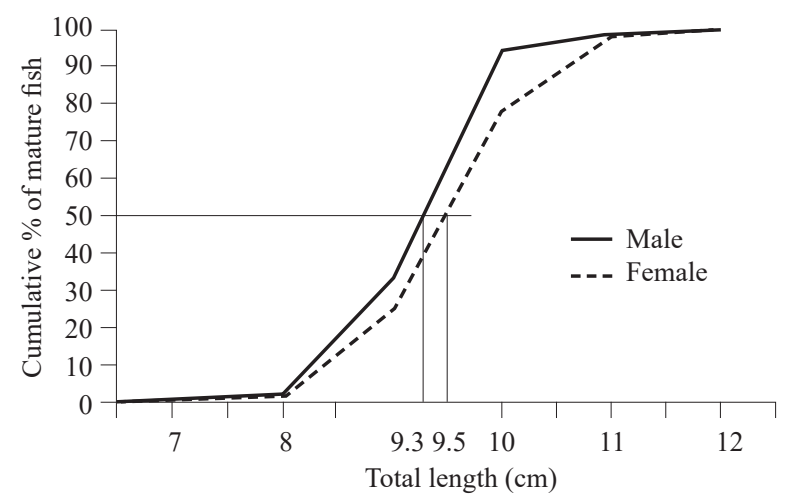

Fig. 2. Length at first maturity of $P$. bindus along Manguluru coast.

Mature adults occurred from October onwards with $100 \%$ mature specimens recorded in February (Fig. 3a, b). The GSI in females was estimated as 0.995 $( \pm 0.8413)$ in stage I; $1.4249( \pm 0.6832)$ in stage II; 2.0349 $( \pm 0.7441)$ in stage III; $2.7568( \pm 0.9161)$ in stage IV and $3.153( \pm 1.1625)$ in stage V. High GSI values in both sexes observed during November-January corresponded with peak spawning activity (Fig. 4). Males had lower gonadosomatic indices than females of corresponding gonad stage of development. This is in line with the assertion that gonado-somatic indices are generally higher in females than males on account of additional weight gain of ovaries in the breeding period as a result of accumulation of yolk in the eggs and also due to uptake of fluid by ripe oocytes (Shinkafi and Ipinjolu, 2012).

Absolute fecundity ranged from 5,715 in a fish of $8.8 \mathrm{~cm}$ TL to 37,160 in a fish of $10.6 \mathrm{~cm}$ TL, with an average of $9349 \pm 853$ eggs. Balan (1967) reported an 


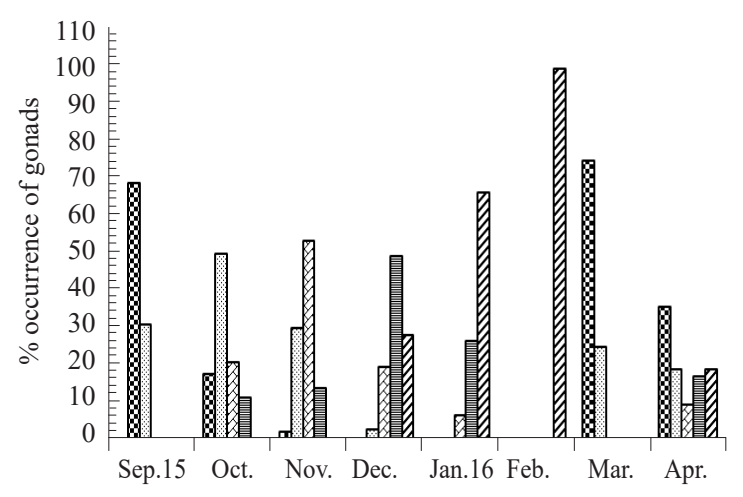

(a)

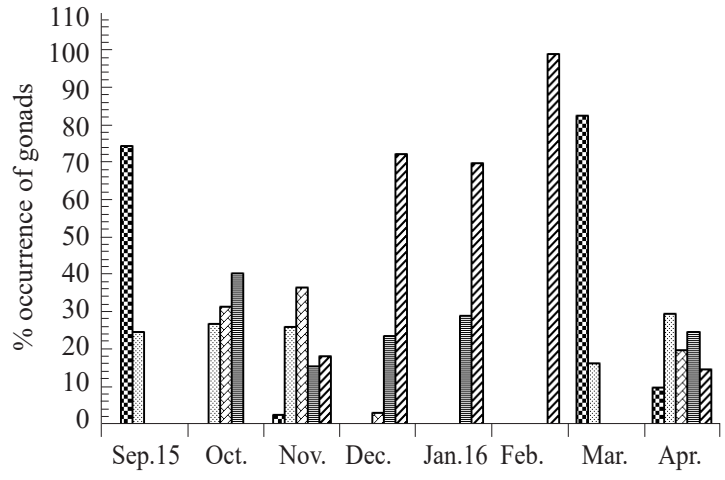

(b)

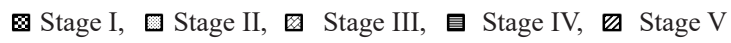

Fig. 3. Monthly variation of maturity stages in (a) Male and (b) Female P. bindus

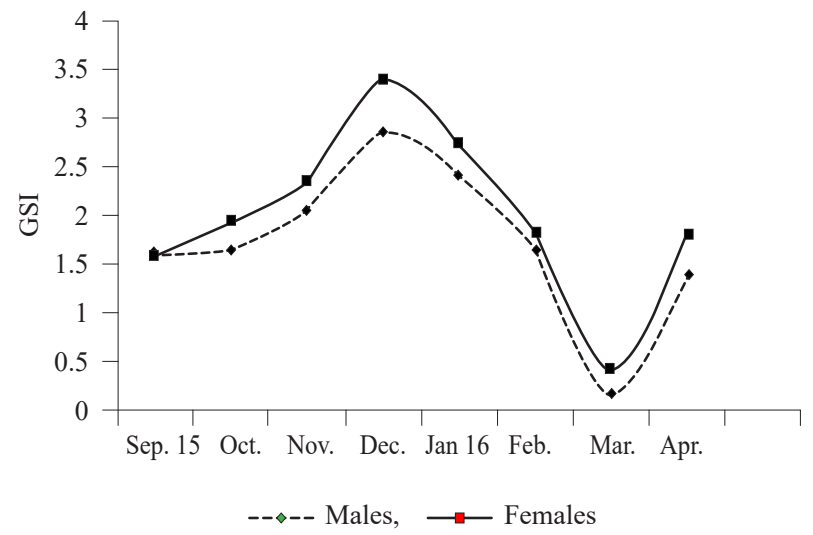

Fig. 4. Monthly gonado-somatic index (GSI) of male and female $P$. bindus off Manguluru

average of 6,162 ripe eggs; with higher fecundity in larger fish upto 7,735 eggs. Rao et al. (2015) reported that the fecundity for this species varied from 6,009 to 18,786 ova. The relation between fecundity and total length/total weight/ovary weight were estimated as:

$$
\begin{aligned}
& \log \text { fecundity }=0.599+3.4017 \log \text { length }\left(R^{2}=0.9389\right) \\
& \log \text { fecundity }=2.4694+1.2816 \log \text { weight }\left(R^{2}=0.7953\right) \\
& \log \text { fecundity }=4.2606+0.9074 \log \text { ovary weight }\left(R^{2}=0.8639\right)
\end{aligned}
$$

The population characteristics of fishes, particularly concerning their reproduction, are important inputs in the assessment and management of fish stocks (Froese, 2004). Reproductive characteristics of stocks form the basis for estimating minimum legal size (MLS) as well as for establishing closed fishing seasons and the compulsory release of live gravid females during catch segregation (Morgan, 2008). The present study provides primary information on the reproductive characteristics of the ornagefin ponyfish off Manguluru, where it forms an important component of the trawl bycatch. The results presented will form a baseline for further research on the stock structure as well as ecological significance of this species.

\section{References}

Abraham, J., Joshi, K. K. and Murty, V. S. R. 2010. Taxonomy of the fishes of the family Leiognathidae (Pisces, Teleostei) from the west coast of India. Zootaxa, 2886: 1-18. DOI: 10.11646/zootaxa.2886.1.1.

Abraham, J., Joshi, K. K. and Murty, V. S. R. 2011. Reproductive biology of Leiognathus splendens (Cuvier) from Kochi, south-west coast of India. Indian J. Fish., 58(3): 23-31.

Balan, V. 1963. Biology of the silverbelly, Leiognathus bindus (Val.) of the Calicut coast. Indian J. Fish., 10(1): 118-134.

Bohlen, J., Freyhof, J. and Nolte, A. 2008. Sex ratio and body size in Cobitis elongatoides and Sabanejewia balcanica (Cypriniformes; Cobitidae) from a thermal spring. Folia Zool., 57: 191-197.

Clark, F. N. 1925. The life history of Leuresthis tenuis, an atherine fish with tide controlled spawning habits. Calif. Fish Game Comm. Fish Bull., 10: 1-51.

CMFRI 2018. Annual Report 2017-2018. Central Marine Fisheries Research Institute, Kochi, India. p. 24.

De Jong, J. K. 1940. A preliminary investigation on the spawning habits of some fishes of the Java Sea. Treubia, 17: 307-327.

De Vlaming, V., Grossman, G. and Chapman, F. 1982. On the use of the gonadosomatic index. Comp. Biochem. Physiol. 73A(1): 31-39. DOI: 10.1016/0300-9629(82)90088-3.

Fricke, R. and Eschmeyer, W. N. 2009. A guide to fish collections in the Catalog of fishes database. http//research.Cal academy.Org/research.Ichthyology/catalog/collections. Asp 
Froese, R. 2004. Keep it simple: three indicators to deal with overfishing. Fish Fish., 5(1): 86-91. doi.org/10.1 111/j.1467-2979.2004.00144.x.

Hickling, C. F. and Rutenberg, E. 1936. The ovary as an indicator of the spawning period in fishes. J. Mar. Biol. Ass. UK, 21: 311-317. DOI: $10.1017 / \mathrm{S} 0025315400011322$.

Imam, A. A., Mekkawy, S. and Hassan, A. A. 2012. Reproductive characteristics of the elephant-snout fish, Mormyrus kannume Forsskal, 1775 from the Nile, Egypt. J. Bio. Sci., 12: 15-24. DOI: 10.3923/jbs.2012.15.24.

Kizhakudan, S. J. and Reddy, P. 2012. Length-weight relationship in three species of silver bellies from Chennai coast. Indian J. Fish., 59(3): 65-68.

Le Cren, E. D. 1951. The length-weight relationship and seasonal cycle in gonad weight and condition in the perch (Perca fluviatilis). J. Anim. Ecol., 20: 201-219.

Morgan, M. J. 2008. Integrating reproductive biology into scientific advice for fisheries management. J. Northwest Atlantic Fish. Sci., 41: 37-51. doi:10.2960/J.v41.m615.

Murty, V. S. R. 1983. Observation on some aspects of the biology of silverbelly Leiognathus bindus (Valenciennes) from Kakinada. Indian J. Fish., 30(1): 61-68.

Murty, V. S. R., Joshi, K. K. and Nair, R. J. 2003. Silver bellies. In: Mohan Joseph, M. and Jayaprakash, A. A. (Eds.),
Status of exploited marine fishery resources of India. Central Marine Fisheries Research Institute, Kochi, India, p. 127-132.

Rossoni, F., Amadio, S., Ferreira, E. and Zuanon, J. 2010 Reproductive and population parameters of discus fish Symphysodon aequifasciatus Pellegrin, 1904 (Perciformes: Cichlidae) from Piagacu-Purus Sustainable Development Reserve (RDS-PP), lower Purus River, Amazonas, Brazil. Neotrop. Ichthyol., 8(2): 379-383. doi.org/10.1590/S167962252010000200018

Shinkafi, B. A. and Ipinjolu, J. K. 2012. Gonadosomatic index, fecundity and egg size of Auchenoglanis occidentalis (Cuvier and Valenciennes) in river Rima, north-western Nigeria. Niger. J. Basic Appl. Sci., 20(3): 217-224.

Wiadnya, D., Widodo, N., Marsoedi, K., Kusuma, W. E., Setyohadi, D. and Soemarno. 2014. Morpho-species of common Silverbellies (Family: Leiognathidae) found in East Java's coastal sea, Indonesia. J. Biol. Environ. Sci., 5(2):107-121.

Rao, Y. P., Naga Krishna Veni, D. and Rukmini Sirisha, I. 2015. Biology of orange fin pony fish, Photopectoralis bindus (Valenciennes, 1835), off Visakhapatnam, east coast of India. Int. J. Environ. Sci., 5(6):1159-1171. 